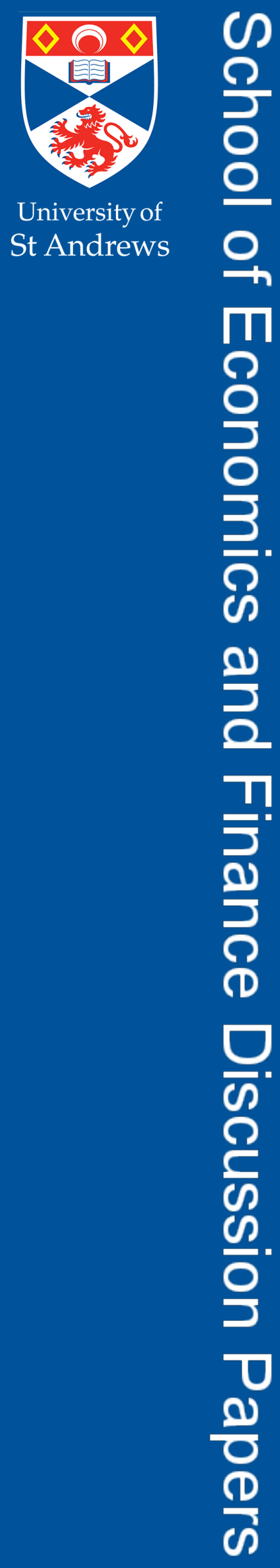

School of Economics and Finance Discussion Paper No. 1901 31 Jan 2019

JEL Classification: D12, G2, Z13

Keywords: financial deleveraging; social insurance; consumption smoothing; microfinance; Andhra Pradesh 


\title{
Social groups and credit shocks: Evidence of inequalities in consumption smoothing
}

\author{
Vibhor Saxena (University of St Andrews, UK) ${ }^{+}$ \\ Ishaan Bindal (National University of Singapore, Singapore) \\ Philippe LeMay-Boucher (Heriot-Watt University, UK)
}

\begin{abstract}
A strand of research holds the view that restricting access to credit to regulate over-borrowing can worsen consumers' financial condition. Another strand of research holds the view that access to credit in the developing countries with subprime credit markets is determined by social groupings and ethnic affiliations. By merging these two strands of research, we investigate the impact of Andhra Pradesh microfinance act (2010) on the consumption expenditure of marginalised social groups and the upper caste Hindu groups in India. We construct an aggregated district level panel data for eight quarters and estimate the impact of unanticipated policy change. The results of our analysis show that the sudden restriction of access to credit has larger impact on the consumption levels of the marginalised social groups: lower castes, tribes, and Muslims. The findings also confirm the failure of contingency policy enacted for smoothing consumption.
\end{abstract}

JEL classification: D12, G2, Z13

Keywords: financial deleveraging; social insurance; consumption smoothing; microfinance; Andhra Pradesh

${ }^{+}$Corresponding author at all stages. 


\section{Introduction}

For the growth of small and medium businesses, literature suggests that the lack of access to credit is a major constraint (Beck and Demirguc-Kunt, 2006). Small businesses are arguably linked with economic growth and poverty alleviation (Snodgrass and Biggs, 1996; Beck and Demirguc-Kunt, 2006), and expanding cheap credit makes the small businesses (weakly) better off. Therefore, they are lucrative for both policy makers and commercial lenders (Karlan and Zinman, 2010; Zinman, 2010). However, the literature and policymakers are divided on the issue of access to subprime credit to consumers (Zinman, 2010). ${ }^{1}$ While some arguments suggest that access to cheap credit can be welfare maximising, (Karlan and Zinman, 2010; Zinman, 2010), contrasting theories suggest time inconsistent biased preferences and excessive liquidity can reduce welfare of the consumers due to underestimation of borrowing cost and over-borrowing (Laibson, 1997). ${ }^{2}$

Especially in the case of informal markets, the concern is of inefficient lending practices at usurious interest rates. To complement these concerns, a body of empirical literature has evolved to vindicate the disadvantages of easy access to consumer credit in incomplete markets (Melzer, 2011; Carrell and Zinman, 2014). ${ }^{3}$ However, there are several others who provide evidence in support of informal credit. The supporters provide evidence that, even if the loans are costly, up to a certain extent, access to credit provides assistance in consumption smoothing to absorb expenditure shocks (Wilson et al., 2010; Morse, 2011). The supporting evidence also states that access to costly credit assists in restricting income uncertainty, health, and financial problems leading to consumption shocks (Morgan and Strain, 2008; Karlan and Zinman, 2010).

Although restriction on access to costly credit through microfinance and other credit agencies is an ongoing debate, in the context of developing countries, the role of social networks based on tribes, kinships, clans and ethnicities in providing credit and other forms of support at the time of contingencies is important. This strand of research has huge amount of literature on community networks in developing countries and their role in bringing economic efficiency by

\footnotetext{
${ }^{1}$ For economically underdeveloped countries, Zinman (2010) specifically mentions that the access to credit to individuals, households, or to enterprises is essentially indistinguishable. Therefore, we do not attempt any distinction between the main purposes of the credit.

${ }^{2}$ Empirical evidence suggest that these behaviour biases are crucial at the micro level where individuals or households develop the tendencies to over borrow and reduce savings (Stango and Zinman, 2009). Similarly, evidence finds subprime rates in the credit card market due to inconsistent consumer behaviour in 1991 in the US (Ausubel, 1991).

${ }^{3}$ An important commonality in the studies by Melzer (2011) and Carrell and Zinman (2014) is the stronger negative effect of costly credit access on the welfare of financially unsophisticated agents and low-income households, respectively.
} 
solving the information and commitment issues (Coleman, 1988; Munshi, 2014). Our focus is mainly on the ubiquitous feature of community networks in the developing countries which provide safety nets to smooth consumption (Townsend, 1994; Mazzocco and Saini, 2012; Munshi and Rosenzweig, 2016).

We contribute to the literature by merging these two main strands of research. We do so by estimating the impact of restricting credit access to prevent over borrowing on different socioeconomic groups. We use a natural experiment of a sudden and forced shutdown of all microfinance industry in the state of Andhra Pradesh (AP), India by an ordinance in October 2010. The sudden ordinance brought the MFIs to its knees and restricted the households' access to credit within the state of AP. ${ }^{4}$ We estimate the impact of this unexpected credit withdrawal on average household consumption at the district level (aggregated) on the whole population of AP, on the higher social groups, and on the marginalised social groups, respectively. Our results indicate that the impact of unexpected credit withdrawal from the market by the AP ordinance had a negative and statistically significant impact on the average consumption of whole population at the district level. Once we separate the data for upper caste social groups, we don't find statistically significant impact on the average household consumption at the district level. However, for the sample of marginalised social groups, the average household consumption at the district level declines after the ordinance.

The plan of the rest of the paper is as follows. In section 2, we discuss the AP ordinance and law which shut the microfinance industry in the state and imposed sudden credit withdrawal from the market. Section 3 presents an overview of the social structure in India and its relevance in post shock consumption smoothing. Section 4 presents identification strategy. Section 5 describes both unit level data, aggregated data, and construction of panels. Section 6 presents estimation results and some robustness checks. Section 7 presents conclusion with policy implications.

\footnotetext{
${ }^{4}$ It is important to note that if the ordinance could have been anticipated, household had adjusted their consumption patterns. However, in this case, the ordinance has widely been considered sudden in the literature where the government of AP acted swiftly and firmly (Taylor, 2011; Mader, 2013).
} 


\section{Microfinance in India and development of Andhra Pradesh ordinance}

\subsection{Microfinance in India}

The main objective of the federal government between 1950s-1980s was to increase access to credit to decrease poverty thorough agriculture. However, without any focus on basic infrastructure of saving mobility and recovery, the extension of state owned formal financial system for informal markets became unsustainable and deemed a failure in mid 1990s (Satish, 2004).

Microfinance started in India in 1980s when Self-Help Groups (SHGs) of females originated in some of the southern states. Initially, these groups were voluntarily organised by the female members for savings, formal agencies (for e.g. National Bank of Agriculture and Rural Development (NABARD)) supported the development of these groups by connecting them to formal banking. However, the expansion of MFIs as a specialised industry started in 1990s. The new entrants followed the model of Grameen Bank and were backed up by the central bank (Reserve Bank of India (RBI)) and NABARD (Mader, 2013). Although India's microfinance industry started late, it yielded immediate results among the poor due to the preexistence of social norms and experience of managing debt. Also, the change in macroeconomic policies of liberalisation in India in early 1990s compressed rural incomes, increasing the demand of debt (Mader, 2013). Population, climate change, and restructuring of risk were other factors. As a result, there has been a constant rise in the percentage of households under debt in India, especially amongst farmers in the rural areas (Taylor, 2011).

\subsection{Development of Andhra Pradesh Ordinance}

While $48.6 \%$ households were indebted in India on average, there was a considerable difference in AP with 82\% indebted households in 2005 (Rao and Suri, 2006). There were several causes of microfinance led debt differential of AP in comparison to other states. First, there was huge change in the state level policies in sponsoring and promoting the microcredit through SHGs and it was nowhere as pronounced as in the state of AP. In the early 2000s, around half of the SHGs of India were based in AP receiving more than fifty percent of total credit from the formal banks under the state policy (NABARD programme) (Taylor, 2011). Second, the World Bank was backing up the reforms agenda of the state government and provided the financial support in promoting microfinance activities in the state. Third, the state government's expansion of microfinance (or SHGs) was not solely based on the objective of poverty reduction - it was also led by the populist idea of retaining the vote share in the state 
after retrenchment of welfare programmes caused by general change in trade policies (Taylor, 2011). Analysing the decentralisation of power, Johnson, Deshingkar and Start, 2005, indicated the political role of SHGs where the incumbent government tried to construct a direct network, bypassing the panchayat (village council) level local political structure. Conditional on these political motives, only around one quarter of all SHGs, mainly established by comparatively better off groups, received access to microcredit.

In India, MFIs can be classified in three main categories: community centric and not backed by formal sector, not-for-profit (or NGOs) cooperatives, and profit maximising non-banking finance companies (NBFCs). NBFCs main purpose is to maximise the returns for investors and these don't intend to serve the purpose of poverty alleviation (Nair, 2010). As the inequality in accessing credit by relatively poorer individuals under state sponsored programmes increased, several NGOs treated it is an opportunity to provide access to the politically constrained groups. These NGOs quickly transformed into NBFCs to provide credit to constrained individuals. Soon these not-for-profit NGOs acted as a financial intermediaries of commercial banks where commercial banks provided the liquidity to lend by buying the NGOs debt portfolios (Sriram, 2010). ${ }^{5}$

This growth of microfinance industry in AP, backed by commercial and formal lenders, created competition in the market of informal credit. Once the shareholders were involved, the profit maximising MFIs expanded and competed for the borrowers. Entry of competitive market practices quickly escalated the slow moving and philanthropic distribution of credit by MFI workers, to commission based and repayment maximising MFI workers. This led to several issues in the microfinance industry of AP. Initially, the objective of commercial MFIs was to target those clients who did not receive credit under the government programmes. However, soon the overlapping started in the form of multiple borrowings, and MFIs started giving loans to SHGs who were already served by the state government (Srinivasan, 2010). Until 2010, AP has the highest concentration of MFI loans and clients. Average loan outstanding for the poor households have reached the unsustainable levels - this figure is around three to nine times more than the other micro-saturated states (Srinivasan, 2010). While vindicating the expansion of clients due to the existing demand of credit, MFIs changed the model of creating

\footnotetext{
${ }^{5}$ Once these NGOs are financial intermediaries, they started charging interest rates of around $25 \%$ and additional charges from SHG clients, while borrowing from commercial banks at the rate of $10 \%-15 \%$ (Taylor, 2011).
} 
opportunities to a demand based model (Mader, 2013). In pursuit of more clients, the structure of group liability of SHGs diluted and MFIs started to lend individuals within the SHGs.

The first episode of this major microfinance crisis of AP was realised in March 2006 in Krishna district. Several borrowers registered complaints of usury and coercive malpractices of loan recovery. ${ }^{6}$ There were also some protests from borrowing groups against the MFIs in certain parts of Krishna District. The allegations that around ten people have committed suicide in Krishna district were also highlighted by the local media houses. Following these complaints and protests, authorities closed around fifty branches of large MFI groups. The issue was also raised at a meeting chaired by the chief minister (CM) of AP on $17^{\text {th }}$ March 2006, who agreed that the MFIs have been involved in the malpractices and transforming into worse than the traditional village level sahukars (Shylendra, 2006). ${ }^{7}$

After the Krishna crisis there was a short pause in the MFIs' lending activates in AP. However, post pause, rather than short-term loans, MFIs received long-term capital investments through domestic and even foreign investors. There were several small MFIs who started to attract funds were termed as "young Turks" just before the major crisis. Gradually, the whole industry turned less risk averse and several episodes similar to Krishna crisis occurred (Sriram, 2010). ${ }^{8}$ Around October 2010, AP MFIs were warned by the Centre of Microfinance, Chennai, about the severity of the debt situation at the household level. The institute estimated that close to $85 \%$ households have two or more loans and around 58\% have four or more loans. Mostly from the informal sources of MFIs and SHGs, the households with multiple finances had borrowed from formal sources and moneylenders too (Mader, 2013).

Just before the ordinance, there were several reports in media of suicides in AP between September-October 2010 due to loan recovery malpractices. On $14^{\text {th }}$ October, the cabinet minister for rural development of AP declared the government would promulgate an ordinance to safeguard MFIs' clients from intimidation and violence by their agents. The state minister's statement was never an unlikely event, due to the regular protests and outcry of borrowers

\footnotetext{
6 In many cultures and countries, these practices include bullying, physical harm, humiliating, shaming, housebreaking, and theft for loan recovery (Sherratt, 2016).

${ }^{7}$ In a follow-up meeting on $20^{\text {th }}$ March 2016, the CM ordered an inquiry of MFIs in three districts of Andhra Pradesh to curb any malpractices or usurious interest rates.

${ }^{8}$ There were several warnings by agencies at home and abroad about the development of MF crisis in Andhra Pradesh between 2009 - 2010. While blame game with the government was on, MFIs constantly ignored these warnings (Mader, 2013).
} 
against the increasing violence of MFI agents (Nagarajul, 2010). ${ }^{9}$ The ordinance by AP government was passed on $15^{\text {th }}$ of October against the backdrop of these reports and incidences. The ordinance mentioned that MFIs charged usurious interest rate and employed loan recovery malpractices, causing physical harm and distress. The ordinance also ordered to register all its employees, publish interest rates clearly, and do not recover loans until it follows the complete registration process (Government of Andhra Pradesh, 2010). Amongst several conditions, the ordinance mainly emphasised the restriction on collection of loan amount by MFIs personnel - any counteraction could have led to arrest of senior employees. The ordinance then enacted into an Act by the parliament in December 2010. The aftermath was catastrophic for the whole industry in the state and substantially reduced the MFIs' access to funds, and thereafter, lending activities, and loan portfolios.

\section{Social structure in India and its importance in consumption smoothing}

\subsection{Social structure in India}

The scheduled caste is the term applied to a wide range of Hindu groups belonging to the lowest rung in the caste hierarchy. They comprise about 16 per cent of India's population and they continue to face many disadvantages, even though discrimination based on caste has been declared illegal in the Indian constitution. The scheduled tribes include most so-called tribal or indigenous communities throughout India. Considered to be outside the Hindu caste system, they comprise about 8 per cent of India's population. Both the scheduled castes and scheduled tribes are widely viewed as being at the lowest level of the social scale. Muslims in India, who comprise about 14 per cent of India's population, are also considered to be considerably deprived in many dimensions (Saxena and Bhattacharya, 2018). ${ }^{10}$

On average, these households are socioeconomically backward compared to the upper caste households and they mostly reside in the poorer neighbourhoods or slums in the urban areas. In the rural areas, the scheduled caste households are often segregated in hamlets outside the main perimeters of the villages. Members of the scheduled tribe communities often live in the relatively remote areas. And while the Muslim communities mostly live in the urban areas,

\footnotetext{
${ }^{9}$ The accusations against MFIs also included kidnapping and forced prostitution of girls from the households who were unable to pay debt (Mader, 2013).

${ }^{10}$ See Sachar Committee Report, (2006). See also Desai and Venna, (2008) and Asadullah and Yalonetzky, (2012).
} 
they live within the city boundaries in Muslim ghettos (Gayer and Jaffrelot, 2012; Saxena and Bhattacharya, 2018).

\subsection{Role in consumption smoothing}

If the social groups are not systematically different in the amount of insurance, then the changes in consumption, post income shock, should be identical. However, one of the earliest studies finds evidence of differences in the amount of social insurance in Indian villages where landless and poor households were less socially insured (Wilson, 1968; Townsend, 1994). More recent research emphasized that the network effects in providing insurance are not restricted to villages and expand through social networks. These networks provide financial flows through loans, transfers, gifts, food consumption, and non-food consumption (Chuang and Schechter, 2015).

In many cases full insurance is not realised due to several constraints or frictions. ${ }^{11}$ In the context of this paper, our objective is not to separately identify and test these theories of constraints. We simply suggest that these all constraints can be caused by ethnic, religious, and caste-based networks. Whether it is limited commitment, or information asymmetry, or cost of building a network link, or interaction of either or all of these, it can be difficult to remove these impediments due to the social structure of India. Therefore, we can deduce that within a given space and time, financial networks of insurance are mainly built across preconstructed socio-cultural lines (Chatterjee and Sarangi, 2005; Guérin and Kumar, 2017).

Following these caveats, the framework of network role and unexpected deleveraging on consumption smoothing can be explained. First, the use of credit available to social groups differs; the less vulnerable, mainly upper caste, dominant social groups are highly likely to invest in activities with higher future returns, whereas, the more vulnerable social groups of lower caste and certain minorities spend the available credit on immediate basic necessities and/or repayment of ongoing debt (Taylor, 2011). Second, because the insurance is provided within the groups, the dominant social groups are more likely to be insured than the lower caste groups.

Considering that the upper caste social groups in India, on average, have relatively more wealth and invested MFI loans productively (Pattenden, 2010), the effect of AP ban could be less severe. Now, if we make a plausible assumption that the upper caste groups have more assets

\footnotetext{
11 These obstructions could be commitment issues, informal asymmetry, and cost to form or remain in the social network (Udry, 1990; Bloch, Genicot and Ray, 2008; Ambrus, Chandrasekhar and Elliott, 2015).
} 
to provide better insurance in their network, we can propose our main conjecture: while the average effect of the AP policy ban on the consumption expenditure of the whole population can be negative, the effect will always be larger in magnitude for the marginalised social groups in comparison to the upper caste Hindu households.

\section{Identification strategy.}

\subsection{Matching}

The first issue to be addressed in identifying the effect of policy is the construction of counterfactuals. In the context of our analysis, we attempt to identify a set of districts that are similar to AP districts in the sample and can be used as a control group in the analysis. Therefore, in our two-step identification strategy of estimating the treatment effect on consumption, we first execute a matching strategy to find an equivalent control group for AP districts.

We use the propensity score matching method proposed by Rosenbaum and Rubin, 1983. For impact evaluation studies, this method has been extensively used and discussed in economic literature (Heckman, Ichimura and Todd, 1997; Dehejia and Wahba, 1999; List, McHone and Millimet, 2004; A. Smith and E. Todd, 2005). Let $Y_{1}$ represent the outcome in the treated group of observations $(T=1$, henceforth $)$ and $Y_{0}$ represent the outcome in the control group $(T=$ 0 , henceforth). ${ }^{12}$ If it is possible to observe both the treated and control districts, the average treatment effect $(A T E)$ would be equal to $\overline{Y_{1}}-\overline{Y_{0}}$ where $\overline{Y_{1}}$ is the average outcome of the treatment group and $\overline{Y_{0}}$ is the average outcome of control group. It is evident that only $\overline{Y_{1}}$ or $\overline{Y_{0}}$ are observable among all the observations. Therefore, in our natural setting, where the policy is not randomly assigned, $A T E \neq \overline{Y_{1}}-\overline{Y_{0}}$. The propensity score method (PSM) by Rosenbaum and Rubin, 1983, shows that conditional on some observable covariates that influence the likelihood of coming under the policy (treatment), $X$, it is possible to compute the probability of treatment for all the districts. These probabilities are called propensity scores, which range from $0-1$ for all the districts, and based on these scores matching can be done for the closest scores between AP and non-AP districts.

\footnotetext{
${ }^{12}$ Please note that we are not using the time subscript for $Y_{T}$, yet. It is because the matching in our analysis is based on cross sectional data, before the treatment took place.
} 
To satisfy the key assumption of conditional independence we need to find a vector of covariates, such that $\overline{Y_{1}}, \overline{Y_{0}}$ is orthogonal to $T \mid X$; or $\overline{Y_{1}}, \overline{Y_{0}} \perp T \mid P(T=1 \mid X){ }^{13}$ The weaker conditional assumption can also be used which states that $E\left[Y_{0} \mid T=1, X\right]=E\left[Y_{0} \mid T=0, X\right]=$ $E\left[Y_{0} \mid X\right]$. Assuming that the conditional independence holds, $Y_{0}$, the consumption outcome of untreated districts $(T=0)$ can be matched with treated districts $(T=1)$ as their unobservable counterfactual employing a matching method. In this case, $\overline{Y_{1}}-\overline{Y_{0}}$ is the average treatment effect of the treated (ATTE) using the counterfactuals post-matching. Our data is of eight quarters at the district level, however, for the matching process we do not classify the prepolicy NSS $66^{\text {th }}$ round sample by quarters and use the whole sample as baseline at the district level. We also use some variables from India census data (2011). Therefore, we are able to match the AP districts with the full sample of more than 400 other districts of India, before the policy ban. While using the probit estimation procedure, we divided the propensity scores in five blocks and conducted balancing test. The balancing property is satisfied, and we get a matched sample of 69 districts. However, two districts had to be dropped due to lack of data of consumption by social groups, reducing the final matched sample to 67 where 21 districts are from AP. ${ }^{14}$

\subsection{Difference-in-difference}

After the matching process, our aim is to evaluate the effect of policy ban on average consumption at the district level for different social groups. Now we have treated AP districts $(T=1)$ and a set of control districts $(T=0)$, and all the districts have been observed for eight time periods (quarters) $t=1$ to 8 for all the social groups. In this case $t=1$ to 4 are pre-treatment time periods and $t=5$ to 8 are post-treatment time periods. Therefore, every outcome observation of average consumption in the data is indexed by $Y_{i t}$ where $i=1, \ldots 67$ and all the observations are repeated for eight time periods with a full sample of $n=536$. Also, the notation for average outcomes will be $\bar{Y}_{0}^{t}$ and $\bar{Y}_{1}^{t}$ for untreated and treated (AP districts), for $t$ time periods, respectively. ${ }^{15}$

On our matched district data of average consumption, we first try to identify the effect of policy by comparing the AP districts before and after the policy change ( $D=1$ for post-treatment time periods or $t=5$ to 8 ; zero otherwise). Considering a linear conditional expectation function

\footnotetext{
${ }^{13}$ Here $T \mid P(T=1 \mid X)$, is the propensity that a district gets treated under the policy and $\perp$ represents independence. ${ }^{14}$ Out of these 69 districts, 22 are from AP and rest of the 47 are from rest of India. Among the two dropped districts, one is Kodagu, from Karnataka, and one is Vizianagaram, from Andhra Pradesh.

${ }^{15}$ Please note that the subscript $(T=0,1)$ refers to treatment status and superscript $(t=1, \ldots 8)$ to quarters.
} 
(Angrist and Pischke, 2009), $Y_{i t}$ ( $\forall i, t$ of AP districts and 1 to 8, respectively), average consumption of AP districts can be modelled by the following equation A and parameters $\alpha_{A}$ and $\delta_{A}$ can be estimated by OLS method:

$$
Y_{i t}=\alpha_{A}+\delta_{A} D+\varepsilon_{i t}
$$

However, the major drawback in this strategy is the time-specific factors. The assumption of $\operatorname{cov}\left(D, \varepsilon_{i t}\right)=0$ will not be satisfied and due to this, $E\left(\hat{\delta}_{A}\right) \neq \delta_{A} \cdot{ }^{16}$

Similarly, a treatment and control estimator can also be used to estimate the policy ban effect by evaluating the average differences in the outcome of AP and non-AP districts, post treatment, i.e, $Y_{i t}$, after ignoring the pre-treatment outcomes. In this case, $Y_{i t}(\forall i, t$ of all districts and 5 to 8 , respectively) of all the districts, post treatment can be modelled by the following equation B and parameters $\alpha_{B}$ and $\delta_{B}$ can be estimated by OLS method:

$Y_{i t}=\alpha_{B}+\delta_{B} T+\varepsilon_{i t}$

Although matching could have reduced the permanent average differences substantially, the treatment effect may not be identified correctly if there exist time invariable differences between AP and non-AP districts. The assumption of $\operatorname{cov}\left(T, \varepsilon_{i t}\right)=0$ will not be satisfied and due to this, $E\left(\hat{\delta}_{B}\right) \neq \delta_{B} \cdot{ }^{17}$

To identify the treatment effect, we finally model the outcome of average consumption expenditure at the district level, $Y_{i t}(\forall i, t)$, as follows in equation $\mathrm{C}$ and estimate the parameter of interest $\delta_{D D}$ by OLS method (Zinman, 2010; Gertler et al., 2016):

$$
Y_{i t}=\alpha_{D D}+\beta_{D D} * T+\sum_{t=2}^{8} \boldsymbol{\tau}_{D D} * \boldsymbol{Q}_{t}+\delta_{D D} *(D . T)+\varepsilon_{i t}
$$

In equation $\mathrm{C}, \alpha_{D D}$ is intercept, $\boldsymbol{Q}_{t}$ is a matrix of dummy covariates of time specific fixed effects (for quarterly data) and $\boldsymbol{\tau}_{D D}$ is a vector of conformable intercept parameters. $(D . T)$ is the main interaction term of AP districts $(T=1)$ with post treatment $(D=1)$ time period. Now, under the exogeneity assumption of $\operatorname{cov}\left((D . T), \varepsilon_{i t}\right)=0, \delta_{D D}$ is correctly identified since, $E\left(\hat{\delta}_{D D}\right)=\delta_{D D}{ }^{18}$

\footnotetext{
${ }^{16} \hat{\delta}_{A}$ here is equal to $\bar{Y}_{1}^{t=1 \text { to } 4}-\bar{Y}_{1}^{t=5 \text { to } 8}$.

${ }^{17} \hat{\delta}_{B}$ here is equal to $\bar{Y}_{1}^{t=5}$ to $8-\bar{Y}_{0}^{t=5 \text { to } 8}$.

$18 \operatorname{cov}\left((D . T), \varepsilon_{i t}\right)=0$ is also known as parallel trend assumption. Employing OLS, $\hat{\delta}_{D D}=\bar{Y}_{1}^{t=1}$ to $4-$ $\bar{Y}_{1}^{t=5 \text { to } 8}-\left(\bar{Y}_{0}^{t=5 \text { to } 8}-\bar{Y}_{0}^{t=1 \text { to } 4}\right)$.
} 


\section{Sample characteristics}

\subsection{Unit level data}

The nationally representative, unit level data used in the analysis come from the National Sample Survey Organisation (NSSO). The NSSO conducts distinct types of surveys in its different rounds, and each round consists of a year's duration. We use NSSO $66^{\text {th }}$ round and $68^{\text {th }}$ round. In both the surveys, detailed information is provided about the consumption expenditure of a unit level household. The households can also be identified by the district and the social group.

Although $66^{\text {th }}$ and $68^{\text {th }}$ rounds of data seem two years apart, we exploit the subrounds of NSSO data. Both the rounds have four subrounds each. Each subround is completed within a quarter and is independent of other subrounds of the same round. ${ }^{19}$ The time chart is as follows: ${ }^{20}$

NSSO $66^{\text {th }}$ Round

(Sub round 1) July - September 2009

(Sub round 2) October - December 2009

(Sub round 3) January - March 2010

(Sub round 4) April - June 2010

Rollout of Ordinance and Law October - Dec 2010

NSS 68 ${ }^{\text {th }}$ Round

(Sub round 1) July - September 2011

(Sub round 2) October - December 2011

(Sub round 3) January - March 2012

(Sub round 4) April - June 2012

It is important to mention that within rounds and subrounds, NSSO also classifies data according to the time frame of consumer expenditure of a household. While schedule type 1 of NSSO records last 30 days consumption expenditure of a household, type 2 records 365 days of consumption expenditure. For 365 days, data is also collected for long term durables. An analysis conducted by the Ministry of Statistics and NSSO experts suggests that the information collected for the shorter time periods substantially reduces measurement error. This is, of

\footnotetext{
${ }^{19}$ Each subround is nationally representative. Normally, an equal number of representative sample villages and urban blocks are allotted to each sub-round in such a manner as to obtain valid estimates for each sub-round (Sastry, 2001).

${ }^{20}$ It can be argued that the law was enacted in December 2010 and the first quarter of data we use, post treatment, is starting from July. However, first, our objective is not to estimate the magnitude of effect; we are simply comparing the group differences at the aggregated level. Second, it has been shown that the effect of the treatment carried until September 2011, before it started to recover in the long run (Renuka and Susan, 2016).
} 
course, true due to intertemporal memory loss for longer time periods and lack of information on exact units of goods purchased. Considering this, we use 30 days reference period (NSSO Expert Group, 2003). This means that the consumption expenditure of a typical household includes information of last 30 days from the time of the survey. ${ }^{21}$ The consumption basked includes all the possible goods at the household level. ${ }^{22}$

\subsection{Aggregated data (district level)}

Once we decided the consumption basket at the household level, we converted the total household expenditure to average household expenditure. For the households in the sample, aggregated household consumption expenditure is constructed at the district level by adding the average household expenditure of each household in the district and dividing the sum by total number of households in the district in the sample. ${ }^{23}$ It is crucial to mention that some concerns have been raised for district level estimates of NSSO data. However, this has been clarified by the NSSO that this issue mainly existed up to the $27^{\text {th }}$ round. Since $27^{\text {th }}$ round, there has been a constant rise in the demand for district level estimates and the agency has complied by treating districts as the ultimate strata (Sastry, 2001). The literature has also used these estimates extensively from $55^{\text {th }}$ round onwards and the aggregates are now considered reliable (Sastry, 2003; Chakraborty, Babu and Chakravorty, 2006; Cutler et al., 2010; Spears, Ghosh and Cumming, 2013). For the set of matching covariates, we have also employed some variables, at the district level aggregates, from Census of India. While most of the variables in Table 1 are from NSS $66^{\text {th }}$ round, considering that the profile of a district to qualify for the AP policy ban requires more covariates, we also relied upon census 2011's district level estimates for economic development and women's agency indicators.

Table 1 provides averages and differences in averages of matching variables at the district level for all the districts pre-matching process. ${ }^{24}$ The first column shows the name of the variables

\footnotetext{
${ }^{21}$ Considering that we are using different time periods for our analysis, we have corrected (deflated) our consumption expenditure according to the point-to-point inflation rates provided by the Government of India. For robustness checks, we also conducted analysis without using the inflation rates and our results don't change. The results without correcting for inflation can be provided on request.

${ }^{22}$ A detailed list of the summary of household's expenditure on all non-durable items in the last 30 days is available with NSSO survey questionnaire (Type 1).

${ }^{23}$ For all district level aggregates of all the variables in the analysis, originating from NSSO data, we used sample weights provided by NSSO for the respective sample units.

${ }^{24}$ In our analysis, we have excluded some of the smaller states and all the union territories of India. We included districts from Andhra Pradesh, Bihar, Chhattisgarh, Gujarat, Haryana, Jharkhand, Karnataka, Kerala, Madhya Pradesh, Maharashtra, Odisha, Punjab, Rajasthan, Tamil Nadu, Uttar Pradesh, Uttaranchal, and West Bengal. In total, we have used 423 districts of India. These districts cover around 95 percent of India's population and are frequently employed at the district level analysis (see, among others, (Bhattacharya, 2006)).
} 
on which we calculate the averages at the district level of all the districts in the sample before the AP policy ban. From NSS $66^{\text {th }}$ round, Dwelling unit is percentage of households in a district with own dwelling, Rural is percentage of households residing in the rural area of a district. Owned any land represents percentage of households in a district with land ownership. Education represents percentage of households in a district with an educated head of household where the head of the household is considered educated (or literate) if he or she has greater than or equal to primary education. Medical facilities, pucca roads, and female labour force participation variables are from census 2011 where medical facilities shows percentage of households with access to medical facilities in a district, pucca roads stands for percentage of villages in a district with access to pucca roads, and female labour force represents percentage of females in the main workforce in a district within the age group of $15-49 .{ }^{25}$ In the context of constructing a list of covariates determining a district's profile for AP policy ban, one of our key variable is the overall indebtedness of a district. Loan outstanding measures the average indebtedness at the household level of rural households in a district where indebtedness is measured by outstanding loans and interest of the rural household.

Using the set of covariates mentioned in Table 1 and matching strategy discussed in section 3 , Table 2 presents estimates of a probit regression where the binary dependent takes value 1 if the district is from AP (treated or $T=1$ ) and zero otherwise. Although we maintain the exogeneity assumption of our matching covariates in predicting propensity scores, it is important to mention that most of the covariates in Table 2 have large and statistically significant effect on the dependent variable. We estimate the predicted propensity (probability) scores from here and match the districts, as mentioned in section $3 .^{26}$ Table 3 presents the descriptive statistics similar to what we have presented in Table 1, however, it is based on the sample of post matching districts. In Table 3, the last column of mean differences between the AP and matched non-AP districts shows that the average differences between the AP and nonAP districts over these matching covariates are not statistically significant for any of them. Most importantly, the last row of the last column in Table 3 shows that the difference in the

\footnotetext{
${ }^{25} \mathrm{~A}$ comprehensive framework of the importance of these variables in determining a district's profile by economic development, productivity, and women's agency is explained in Bhattacharya, 2006.

${ }^{26}$ Here the probit model can be expressed in terms of probability for a binary outcome variable, $\operatorname{Prob}(y=1)=$ $1-F(-())=.F()=.\Phi($.$) , where the general form of the CDF of error term is replaced by the standard normal$ $\mathrm{CDF}, \Phi$. Therefore, for the nonevent $\operatorname{Prob}(y=0)=1-\Phi($.$) . Note, the argument of F$, (.), is straightforward and neglected here.
} 
average indebtedness of the households at the district level between AP and non-AP districts is now only around 1800 Rupees and is insignificant.

\section{Estimation results}

\subsection{Regression estimates}

We first present the results of the estimation of treatment effect by using equation A in Table 4. In our before and after estimation process, we find that the average consumption of the whole sample (All social groups) in the first column before the treatment is around 4532.1 Rupees. Once we divide the sample into social groups, we find a standard result of Hindus having, on average, higher consumption than the marginalised social groups' sample in the second and third column, respectively. However, the coefficient of change after policy ban is positive and statistically significant in all three cases. This indicates that, post AP policy ban, on average, the average consumption of AP districts have increased in our sample. This is a plausible result, considering that there is no counterfactual in this estimation and the rise in the consumption is simply due to time. Although we do not see a negative effect, post-treatment, in a restricted sample of AP districts, a comparison of the effect of treatment on different social groups is interesting Table 4. Our results suggest that the rise in the average consumption at the district level, on average, post-treatment, is higher for Hindus in comparison to the marginalised social groups.

Table 5 shows the estimated effect of AP policy ban by using equation B. In this case, while we have counterfactual districts, the sample is restricted to post-treatment time periods. First, as expected, the average consumption (constant) across all the districts is higher in comparison to Table 4, which, of course, due to the fact of pre and post time differences. Pertaining to our main discussion of social groups, similar to Table 4, the average consumption is higher for Hindus in comparison to marginalised social groups. Once we restrict the sample to posttreatment period, and estimate the treatment effect, the effect is negative and statistically significant in all three columns. Although our treatment effect is biased, the results support our hypothesis in Table 5. The effect of the AP-policy ban has significantly reduced the average consumption of AP districts on the sample of all social groups in comparison to the counterfactuals, the effect is larger in magnitude on the sample of marginalised social groups in comparison to the sample of upper caste Hindu households. 
While Table 4 and Table 5 provide critical support to our hypotheses, our main results are presented in Table 6 . The coefficients in Table 6 have been estimated using equation $C$ on full data. The post-treatment estimates of time specific fixed effects are all positive and statistically significant, while none of the pre-treatment coefficients are significant. This justifies the time trend in Table 5, due to which the treatment effect was positive. Our main result is the difference-in-difference coefficient estimates of the first row. While the effect of the AP policy ban is negative and statistically significant on average consumption expenditure at the district level for the whole sample, it is statistically insignificant in the restricted sample of upper caste Hindus. However, the effect of the policy ban is negative and statistically significant for the marginalised social groups of scheduled caste, scheduled tribes, and Muslims in the sample. Although the coefficient of treatment effect for the upper caste Hindu groups is statistically insignificant, similar to the previous results and pertaining to our Hypothesis, the magnitude is less than the coefficient of treatment effect of the marginalised social groups.

\subsection{Robustness checks}

Tables $7-10$ present the results of estimated effect of the policy ban by restricting the sample to only two quarters where we have fixed the pre-treatment quarter to fourth quarter from the full sample (latest quarter before the policy ban in data) and varied the post-treatment quarter from fifth to eight in the Tables $7-10$, respectively. While Table 7 shows a negative and statistically significant treatment effect for all the social groups, the coefficient of Hindus is insignificant. Also, the average treatment effect is larger in magnitude for the marginalised social groups and statistically significant. The coefficients of treatment effects of social groups are statistically insignificant in the rest of the tables, however, the magnitude of the negative average effect is larger for the marginalised social groups, except in Table 9 where the coefficient of the effect for the total sample is statistically insignificant and positive, and the difference is negligible and less than hundred Rupees. Overall, the set of results in Tables $7-$ 10 underpin our main conjecture that if the AP policy ban of financial deleveraging had a significant effect on consumption, the magnitude has been larger on the socially marginalised groups' sample even in the case of different time periods.

Table 11 presents results of testing for parallel trends assumption of our difference-indifference estimates discussed above. These estimates in Table 11 are obtained by regressing the district level average consumption on quarter fixed effects, treatment fixed effect, and interaction of quarter effects with treatment effect (this can also be termed as a more 
generalised form of difference-in-difference estimation process where treatment is allowed at different times) (Autor, 2003). ${ }^{27}$ For simplicity, in Table 11, we omit the coefficient estimates of time fixed effects and treatment fixed effect. In comparison to the base category, our results suggest that the coefficient estimates of all the pre-treatment interaction variables are statistically insignificant, except in the case of Hindus only in the quarter just before the treatment. Our most important result is the first column of estimates of all social groups where there is no sign of parallel trends assumption before the treatment, but the post-treatment effects are negative and statistically significant.

\section{Conclusion}

We discussed the issues of time inconsistent preferences, usurious interest rates and informal markets in developing countries and concerns raised by both policy makers and in the literature regarding access to informal credit. We also discussed a counterview in the literature which suggests that access to cheap credit provides assistance in consumption smoothing and restricting credit access will have negative effects. Employing the social network literature, we developed our main argument that while the total effect of financial deleveraging (restricting credit) depends on the average insurance of the population, the effect of deleveraging will always be higher on the marginalised social groups in comparison to the social groups with more wealth and insurance.

To test our proposition, we exploited a natural experiment of AP ordinance and social structure of India. While the AP ordinance suddenly reduced the MFIs' lending activities in the state and reduced the overall consumption expenditure across the whole affected population, due to the classified network effects, the effect of financial deleveraging was significantly more on the marginalised social groups. Although out results of sudden financial deleveraging and its negative effects on consumer welfare align with the existing literature in may ways (Zinman, 2010), we propose a novel evidence of the role of social networks and insurance in consumption smoothing post financial deleveraging. Our main results, presented in Table 6, support our proposition that the marginalised social groups differ in the context of the effect of financial deleveraging on consumption expenditure.

\footnotetext{
${ }^{27}$ The base category in this model is the interaction variable of $1^{\text {st }}$ quarter of data (pre-treatment) and the treated districts.
} 
Finally, considering the importance of social networks in several developing countries (Munshi, 2014; Munshi and Rosenzweig, 2016), the literature out rightly rejecting access to cheap credit needs to be more critical in supporting the findings, especially at the time of contingency. Also, nationally representative data of other countries where social networks play key role in informal insurance at the time of contingency can be used to test the effects of financial deleveraging. This would help in addressing the concerns of country specific effects and provide much needed further evidence of effect of restricting credit on different types of social groups. 


\section{References}

A. Smith, J. and E. Todd, P. (2005) 'Does matching overcome LaLonde's critique of nonexperimental estimators?', Journal of Econometrics. North-Holland, 125(1-2), pp. 305-353. doi: 10.1016/J.JECONOM.2004.04.011.

Ambrus, A., Chandrasekhar, A. and Elliott, M. (2015) Social Investments, Informal Risk Sharing, and Inequality, SSRN. 179. doi: 10.2139/ssrn.2518618.

Angrist, J. D. and Pischke, J.-S. (2009) Mostly harmless econometrics : an empiricist's companion. Princeton University Press. Available at: https://press.princeton.edu/titles/8769.html (Accessed: 11 May 2018).

Asadullah, M. N. and Yalonetzky, G. (2012) 'Inequality of Educational Opportunity in India: Changes Over Time and Across States', World Development. Pergamon, 40(6), pp. 1151-1163. doi: 10.1016/J.WORLDDEV.2011.11.008.

Ausubel, L. M. (1991) 'The Failure of Competition in the Credit Card Market', The American Economic Review, 81(1), pp. 50-81. Available at: http://www.jstor.org/stable/2006788 (Accessed: 4 August 2017).

Autor, D. H. (2003) 'Outsourcing at Will: The Contribution of Unjust Dismissal Doctrine to the Growth of Employment Outsourcing', Journal of Labor Economics. The University of Chicago Press, 21(1), pp. 1-42. doi: $10.1086 / 344122$.

Beck, T. and Demirguc-Kunt, A. (2006) 'Small and medium-size enterprises: Access to finance as a growth constraint', Journal of Banking \& Finance, 30(11), pp. 2931-2943. doi: 10.1016/j.jbankfin.2006.05.009.

Bhattacharya, P. C. (2006) 'Economic Development, Gender Inequality, and Demographic Outcomes: Evidence from India', Population and Development Review. Blackwell Publishing Inc, 32(2), pp. 263-292. doi: 10.1111/j.1728-4457.2006.00118.x.

Bloch, F., Genicot, G. and Ray, D. (2008) 'Informal insurance in social networks', Journal of Economic Theory, 143, pp. 36-58. doi: 10.1016/j.jet.2008.01.008.

Carrell, S. and Zinman, J. (2014) 'In Harm's Way? Payday Loan Access and Military Personnel Performance', Review of Financial Studies. Diane Publishing Company, Darby, PA, 27(9), pp. 2805-2840. doi: $10.1093 / \mathrm{rfs} / \mathrm{hhu} 034$

Chakraborty, D., Babu, D. S. and Chakravorty, M. (2006) 'Atrocities on Dalits: What the District Level Data Say on Society-State Complicity’, Economic and Political Weekly. Economic and Political Weekly, 41(24), pp. 24782481. doi: $10.2307 / 4418355$.

Chatterjee, P. and Sarangi, S. (2005) Social Identity and Group Lending. UWEC-2005-06-R. Available at: https://papers.ssrn.com/soL3/papers.cfm?abstract_id=716503 (Accessed: 9 November 2017).

Chuang, Y. and Schechter, L. (2015) 'Social Networks in Developing Countries', Annual Review of Resource Economics. Annual Reviews, 7(1), pp. 451-472. doi: 10.1146/annurev-resource-100814-125123.

Coleman, J. S. (1988) 'Social Capital in the Creation of Human Capital', American Journal of Sociology. The University of Chicago Press, 94, pp. S95-S120. doi: 10.2307/2780243.

Cutler, D. et al. (2010) 'Early-life Malaria Exposure and Adult Outcomes: Evidence from Malaria Eradication in India', American Economic Journal: Applied Economics, 2(2), pp. 72-94. doi: 10.1257/app.2.2.72.

Dehejia, R. H. and Wahba, S. (1999) 'Causal Effects in Nonexperimental Studies: Reevaluating the Evaluation of Training Programs', Journal of the American Statistical Association, 94(448), pp. 1053-1062. doi: 10.1080/01621459.1999.10473858.

Desai, S. and Veena, K. (2008) 'Changing Educational Inequalities in India in the Context of Affirmative Action', Demography. Springer-Verlag, 45(2), pp. 245-270. doi: 10.1353/dem.0.0001.

Gayer, L. and Jaffrelot, C. (2012) Muslims in Indian Cities: Trajectories of Marginalisation. London: Hurst \& Company.

Gertler, P. J. et al. (2016) Impact Evaluation in Practice, Second Edition. The World Bank. doi: 10.1596/978-14648-0779-4. 
Government of Andhra Pradesh (2010) The Andhra Pradesh Micro Finance Institutions Ordinance, Panchayat Raj and Rural Development. Government of Andhra Pradesh. Available at: http://apmfi.cgg.gov.in/downloads/2010PR_MS356.PDF (Accessed: 4 November 2017).

Guérin, I. and Kumar, S. (2017) 'Market, Freedom and the Illusions of Microcredit. Patronage, Caste, Class and Patriarchy in Rural South India', The Journal of Development Studies. Routledge, 53(5), pp. 741-754. doi: 10.1080/00220388.2016.1205735.

Heckman, J. J., Ichimura, H. and Todd, P. E. (1997) 'Matching As An Econometric Evaluation Estimator: Evidence from Evaluating a Job Training Programme', The Review of Economic Studies. Oxford University Press, 64(4), pp. 605-654. doi: 10.2307/2971733.

Johnson, C., Deshingkar, P. and Start, D. (2005) 'Grounding the State: Devolution and Development in India's Panchayats', Journal of Development Studies. Taylor \& Francis Ltd, 41(6), pp. 937-970. doi: 10.1080/00220380500155197.

Karlan, D. and Zinman, J. (2010) 'Expanding Credit Access: Using Randomized Supply Decisions to Estimate the Impacts', Review of Financial Studies. IBRD/The World Bank, Washington, DC, 23(1), pp. 433-464. doi: 10.1093/rfs/hhp092.

Laibson, D. (1997) 'Golden Eggs and Hyperbolic Discounting', The Quarterly Journal of Economics. Oxford University Press, 112(2), pp. 443-478. doi: 10.1162/003355397555253.

List, J. A., McHone, W. W. and Millimet, D. L. (2004) 'Effects of environmental regulation on foreign and domestic plant births: is there a home field advantage?', Journal of Urban Economics. Academic Press, 56(2), pp. 303-326. doi: 10.1016/J.JUE.2004.03.007.

Mader, P. (2013) 'Rise and Fall of Microfinance in India: The Andhra Pradesh Crisis in Perspective', Strategic Change. John Wiley \& Sons, Ltd., 22(1-2), pp. 47-66. doi: 10.1002/jsc.1921.

Mazzocco, M. and Saini, S. (2012) 'Testing Efficient Risk Sharing with Heterogeneous Risk Preferences', American Economic Review, 102(1), pp. 428-468. doi: 10.1257/aer.102.1.428.

Melzer, B. T. (2011) 'The Real Costs of Credit Access: Evidence from the Payday Lending Market*', The Quarterly Journal of Economics. Georgetown University, McDonough School of Business, 126(1), pp. 517-555. doi: 10.1093/qje/qjq009.

Morgan, D. P. and Strain, M. R. (2008) Payday Holiday: How Households Fare after Payday Credit Bans. New York. Available at: https://www.newyorkfed.org/research/staff_reports/sr309.html (Accessed: 5 August 2017).

Morse, A. (2011) 'Payday lenders: Heroes or villains?', Journal of Financial Economics, 102(1), pp. 28-44. doi: 10.1016/j.jfineco.2011.03.022.

Munshi, K. (2014) 'Community Networks and the Process of Development', Journal of Economic Perspectives, 28(4), pp. 49-76. doi: 10.1257/jep.28.4.49.

Munshi, K. and Rosenzweig, M. (2016) 'Networks and Misallocation: Insurance, Migration, and the Rural-Urban Wage Gap', American Economic Review, 106(1), pp. 46-98. doi: 10.1257/aer.20131365.

Nagarajul, J. (2010) 'MFI agents “forcing” debtors to commit suicide', The Times of India, 20 October. Available at: $\quad$ https://timesofindia.indiatimes.com/india/MFI-agents-forcing-debtors-to-commit-suicideStudy/articleshow/6778229.cms.

Nair, T. S. (2010) 'Commercial Microfinance and Social Responsibility: A Critique', Economic and Political Weekly, 45(31), pp. 32-37. Available at: http://www.jstor.org/stable/20764361 (Accessed: 1 November 2017).

NSSO Expert Group (2003) 'Suitability of Different Reference Periods for Measuring Household Consumption: Results of a Pilot Survey', Economic and Political Weekly. Economic and Political Weekly, 38(4), pp. $307-321$. doi: $10.2307 / 4413129$.

Pattenden, J. (2010) 'A neoliberalisation of civil society? Self-help groups and the labouring class poor in rural South India', The Journal of Peasant Studies. Taylor \& Francis, 37(3), pp. 485-512. doi: $10.1080 / 03066150.2010 .494372$.

Rao, P. N. and Suri, K. C. (2006) 'Dimensions of Agrarian Distress in Andhra Pradesh', Economic and Political Weekly, 41(16), pp. 1546-1552. Available at: http://www.jstor.org/stable/4418113 (Accessed: 31 October 2017). 
Renuka, S. and Susan, T. (2016) 'The Real Cost of Credit Constraints: Evidence from Micro-finance', The B.E. Journal of Economic Analysis \& Policy. De Gruyter, 16(1), pp. 151-183. doi: https://doi.org/10.1515/bejeap2014-0154.

Rosenbaum, P. R. and Rubin, D. B. (1983) 'The Central Role of the Propensity Score in Observational Studies for Causal Effects', Biometrika. Oxford University PressBiometrika Trust, 70(1), p. 41. doi: 10.2307/2335942.

Sachar Committee Report (2006) Social, Economic and Educational Status of the Muslim Community of India. New Delhi. Available at: http://mhrd.gov.in/sites/upload_files/mhrd/files/sachar_comm.pdf (Accessed: 24 October 2017).

Sastry, N. S. (2001) Concepts and Definitions Used in NSS, Golden jubilee publication. Available at: http://mospi.nic.in/sites/default/files/publication_reports/concepts_golden.pdf.

Sastry, N. S. (2003) 'District Level Poverty Estimates: Feasibility of Using NSS Household Consumer Expenditure Survey Data', Economic and Political Weekly. Economic and Political Weekly, 38(4), pp. 409-412. doi: $10.2307 / 4413140$.

Satish, P. (2004) 'Rural Finance: Role of State and State-Owned Institutions', Economic and Political Weekly. Economic and Political Weekly, 39(12), pp. 1321-1330. doi: 10.2307/4414811.

Saxena, V. and Bhattacharya, P. C. (2018) 'Inequalities in LPG and electricity consumption in India: The role of Caste, Tribe, and religion', Energy for Sustainable Development, 42(C), pp. 44-53. doi: https://doi.org/10.1016/j.esd.2017.09.009.

Sherratt, L. (2016) Can microfinance work?: how to improve its ethical balance and effectiveness. New York: Oxford University Press. Available at: https://books.google.co.uk/books?id=fmvQCgAAQBAJ\&pg=PR16\&lpg=PR16\&dq=coercive+loan+practice\&s ource=bl\&ots=7ksY_QrwRf\&sig=1ESIvuTrF_UoDto0u3kvBpwgB2s\&hl=en\&sa=X\&ved=0ahUKEwip_4f895 XAhXCD8AKHZoQAp0Q6AEIKDAA\# $\mathrm{v}=$ onepage $\& \mathrm{q}=$ coercive loan practice $\& \mathrm{f}=$ false $\quad$ (Accessed: 2 November 2017).

Shylendra, H. S. (2006) 'Microfinance Institutions in Andhra Pradesh: Crisis and Diagnosis', Economic and Political Weekly. Economic and Political Weekly, 41(20), pp. 1959-1963. doi: 10.2307/4418232.

Snodgrass, D. R. and Biggs, T. (1996) Industrialization and the small firm: Patterns and Policies. San Francisco: International Center for Economic Growth. Available at: http://213.154.74.164/invenio//record/4603/files/pnaca514.pdf (Accessed: 4 August 2017).

Spears, D., Ghosh, A. and Cumming, O. (2013) 'Open Defecation and Childhood Stunting in India: An Ecological Analysis of New Data from 112 Districts', PLoS ONE. Public Library of Science (PLOS), 8(9). doi: 10.1371/journal.pone.0073784.

Srinivasan, N. (2010) Microfinance India: State of the Sector Report 2010. New Delhi: Sage Publications. Available at: https://www.microfinancegateway.org/sites/default/files/mfg-en-paper-microfinance-india-state-ofthe-sector-report-2010-2010.pdf (Accessed: 2 November 2017).

Sriram, M. S. (2010) 'Commercialisation of Microfinance in India: A Discussion of the Emperor's Apparel', Economic and Political Weekly. Economic and Political Weekly, 45(24), pp. 65-73. doi: 10.2307/40738497.

Stango, V. and Zinman, J. (2009) 'Exponential Growth Bias and Household Finance', The Journal of Finance. Blackwell Publishing Inc, 64(6), pp. 2807-2849. doi: 10.1111/j.1540-6261.2009.01518.x.

Taylor, M. (2011) “"Freedom from Poverty is Not for Free”: Rural Development and the Microfinance Crisis in Andhra Pradesh, India', Journal of Agrarian Change. Blackwell Publishing Ltd, 11(4), pp. 484-504. doi: 10.1111/j.1471-0366.2011.00330.x.

Townsend, R. M. (1994) 'Risk and Insurance in Village India', Econometrica. The Econometric Society, 62(3), pp. 539-591. doi: 10.2307/2951659.

Udry, C. (1990) 'Credit Markets in Northern Nigeria: Credit as Insurance in a Rural Economy', The World Bank Economic Review, 4(3), pp. 251-269. Available at: http://www.jstor.org/stable/3989877 (Accessed: 9 November 2017).

Wilson, B. J. et al. (2010) 'An Experimental Analysis of the Demand for Payday Loans An Experimental Analysis 
of the Demand for Payday Loans', The B.E. Journal of Economic Analysis \& Policy, $10(1$ (Topics)), p. Article 93. Available

at: https://www.degruyter.com/downloadpdf/j/bejeap.2010.10.1/bejeap.2010.10.1.2563/bejeap.2010.10.1.2563.pdf (Accessed: 4 August 2017).

Wilson, R. (1968) 'The Theory of Syndicates', Econometrica. The Econometric Society, 36(1), p. 119. doi: 10.2307/1909607.

Zinman, J. (2010) 'Restricting consumer credit access: Household survey evidence on effects around the Oregon rate cap', Journal of Banking \& Finance, 34, pp. 546-556. doi: 10.1016/j.jbankfin.2009.08.024. 


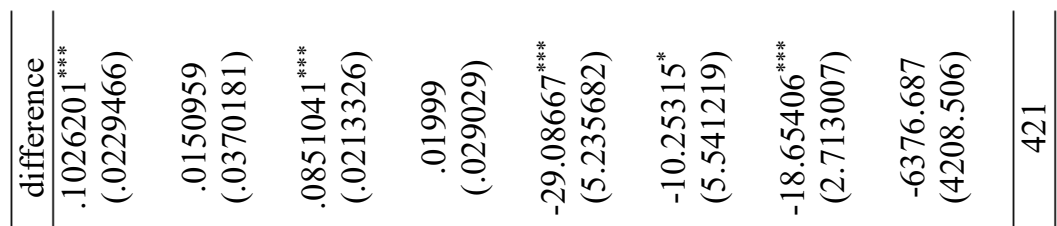

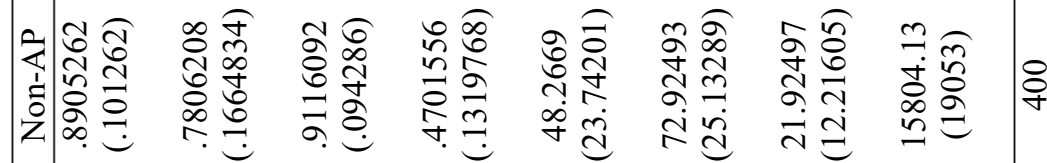

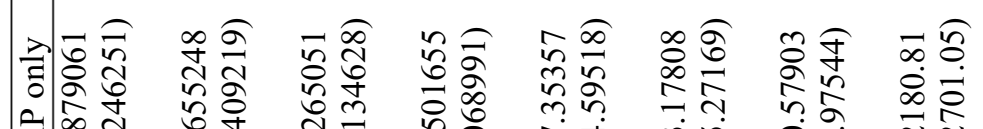

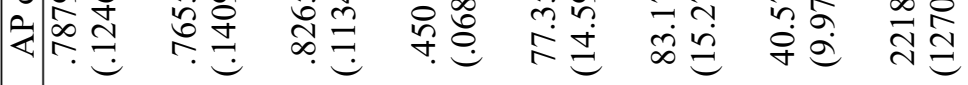

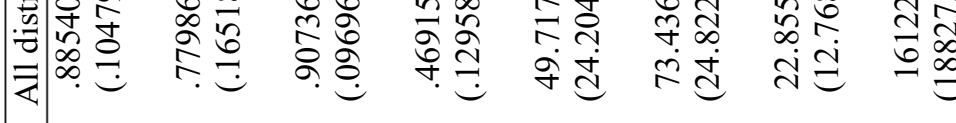

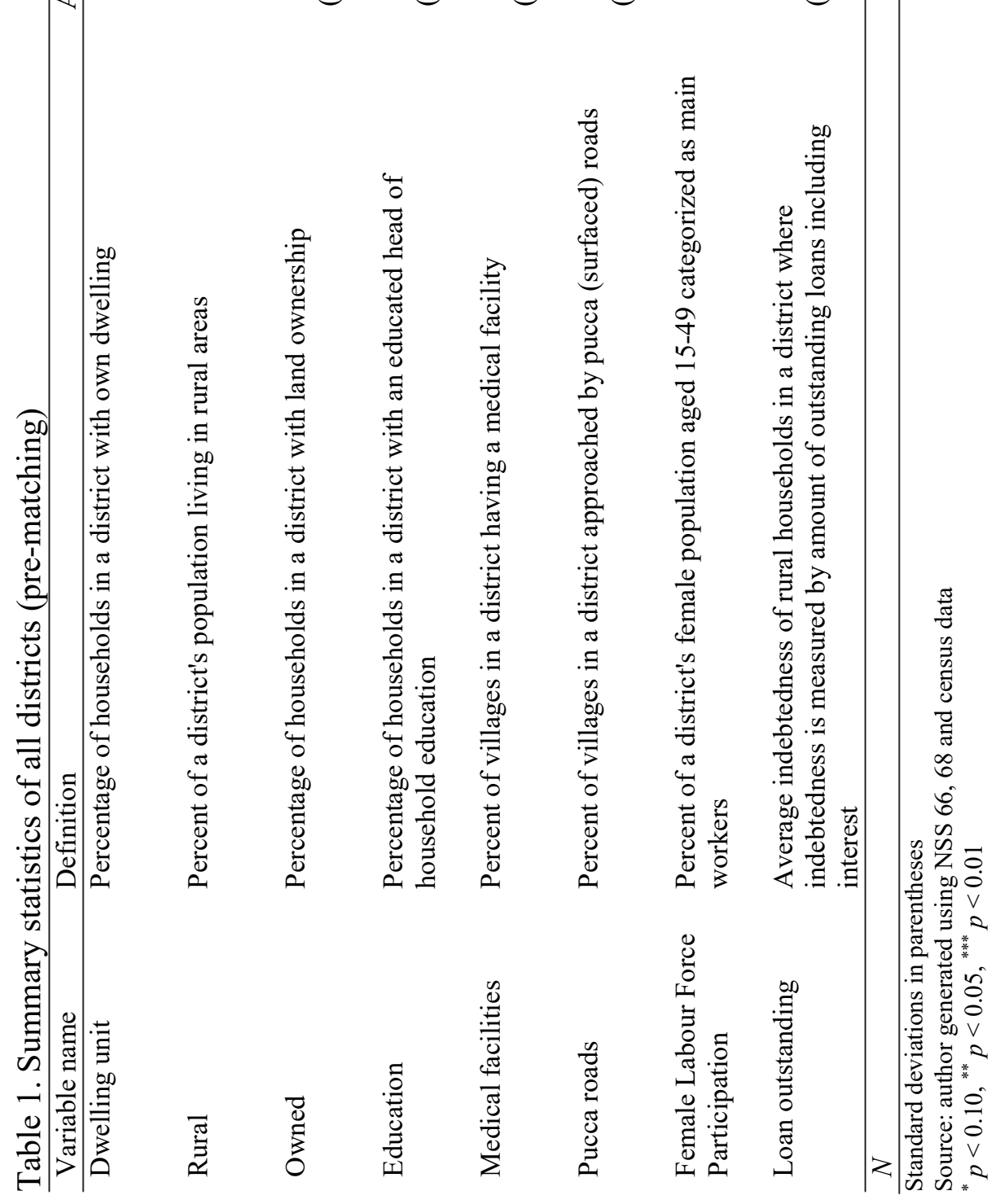




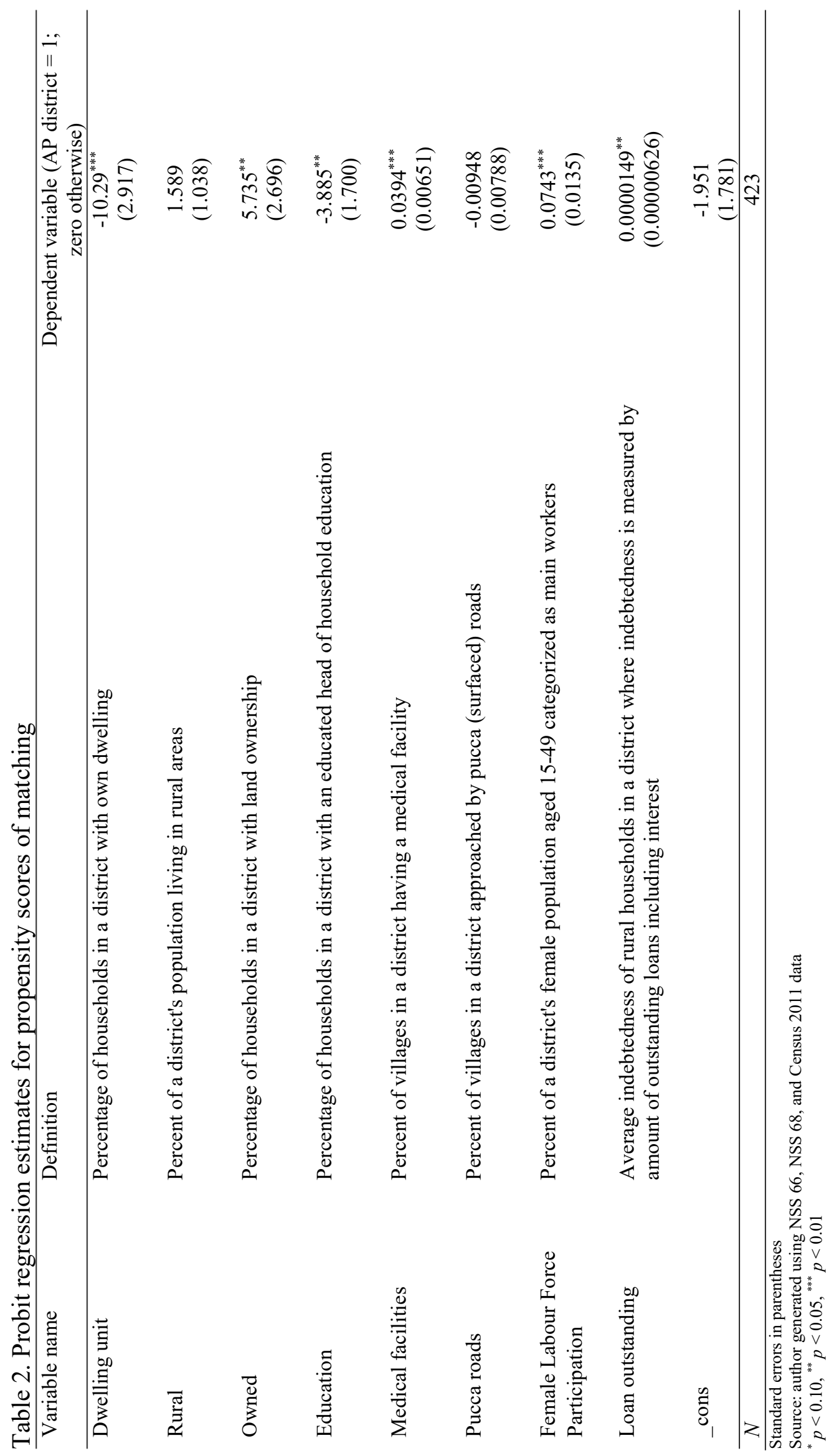




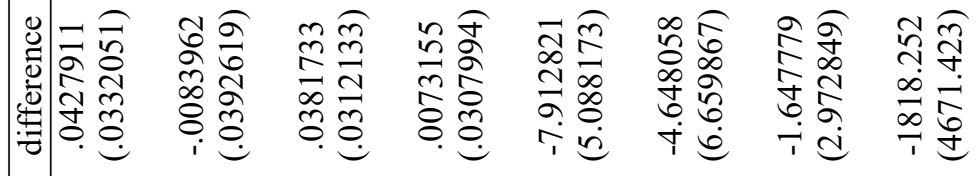

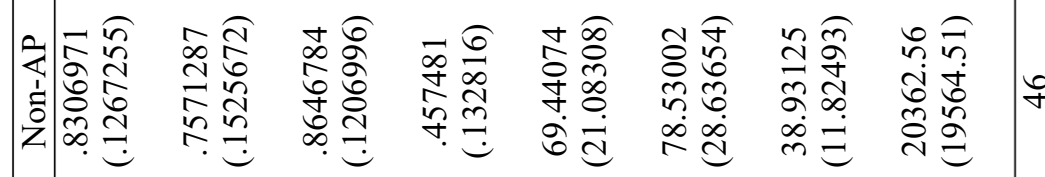

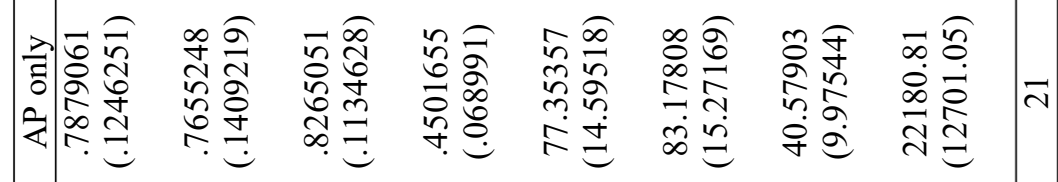

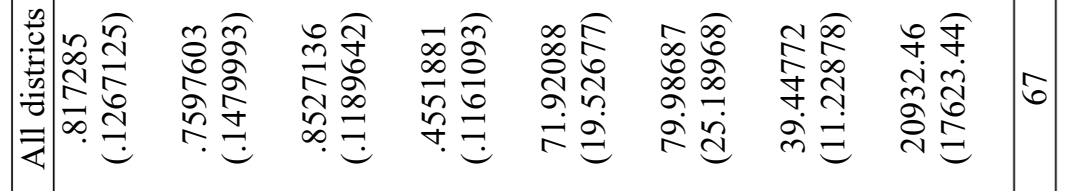

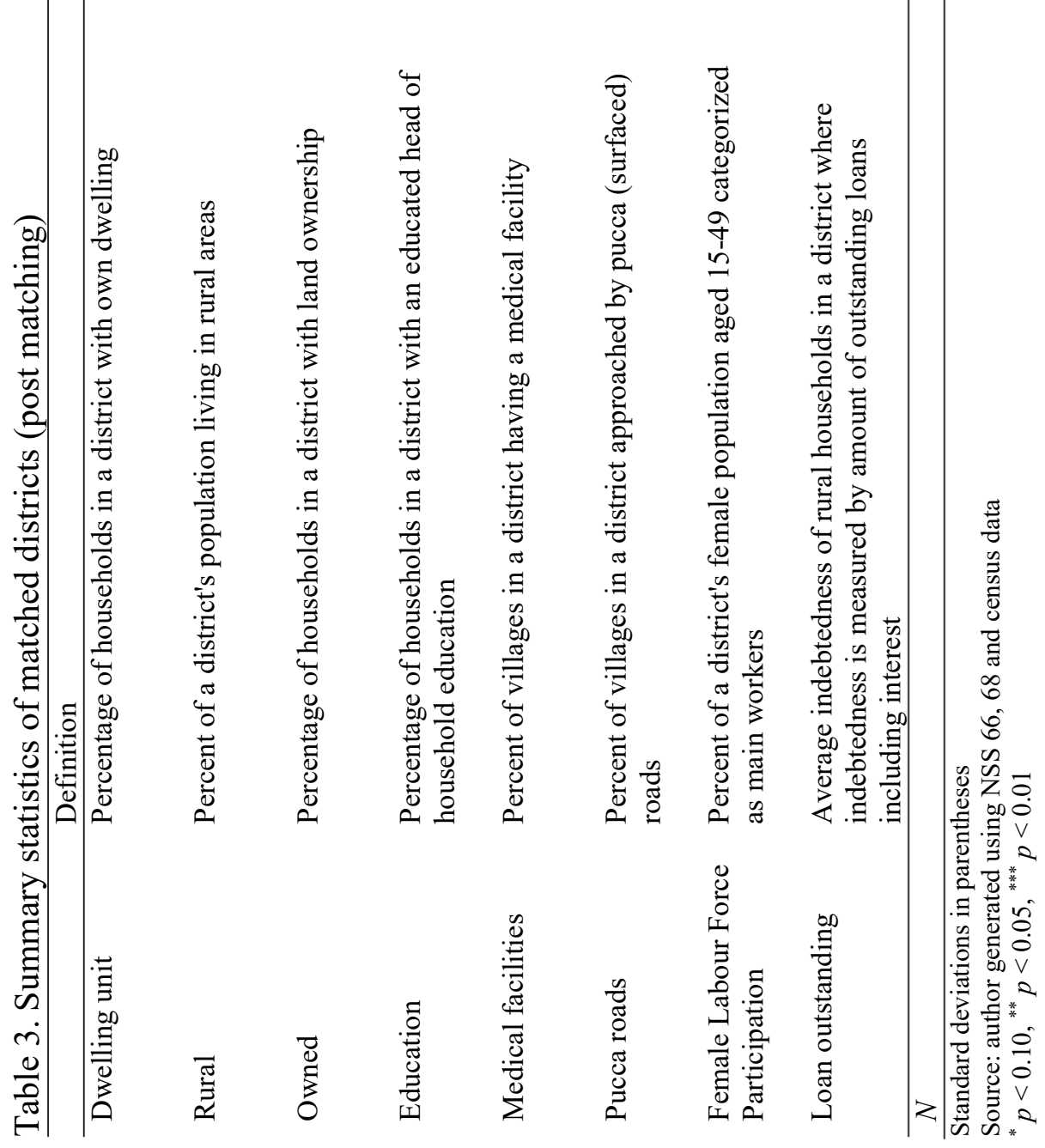




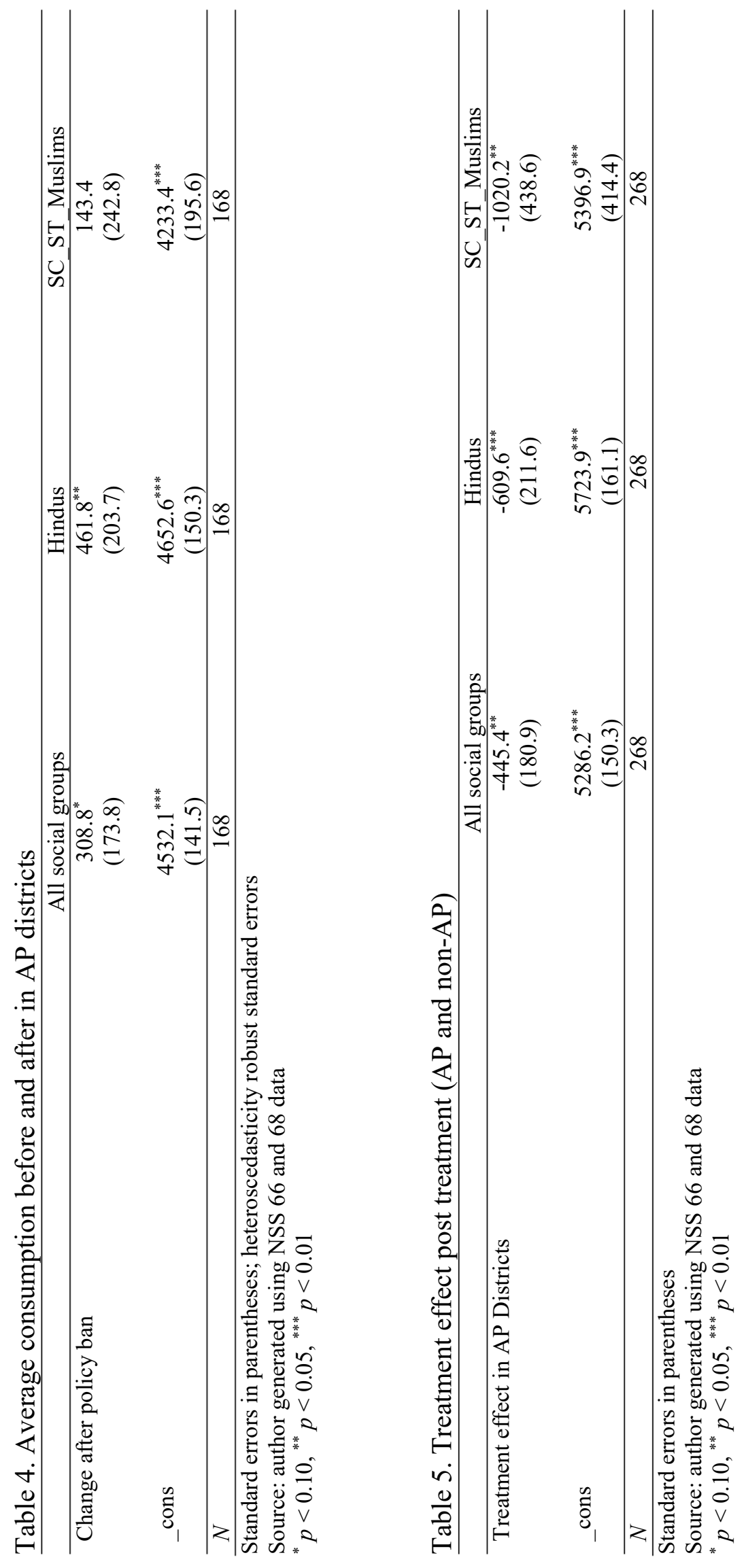


Table 6. Difference-in-Difference estimation using full sample

\begin{tabular}{|c|c|c|c|}
\hline & All social groups & Hindus & SC_ST_Muslims \\
\hline diff-in-diff treatment effect & $\begin{array}{l}-475.4^{*} \\
(259.4)\end{array}$ & $\begin{array}{l}-400.8 \\
(299.2)\end{array}$ & $\begin{array}{c}-1135.0^{* *} \\
(498.7)\end{array}$ \\
\hline Treated districts $=1$; Zero otherwise & $\begin{array}{c}30.06 \\
(184.8)\end{array}$ & $\begin{array}{l}-208.8 \\
(210.2)\end{array}$ & $\begin{array}{c}114.8 \\
(236.6)\end{array}$ \\
\hline October - December 2009 & $\begin{array}{c}44.50 \\
(265.7)\end{array}$ & $\begin{array}{c}87.55 \\
(326.3)\end{array}$ & $\begin{array}{l}-80.69 \\
(314.6)\end{array}$ \\
\hline January - March 2010 & $\begin{array}{l}-303.2 \\
(229.8)\end{array}$ & $\begin{array}{l}-325.6 \\
(298.5)\end{array}$ & $\begin{array}{l}-253.7 \\
(265.0)\end{array}$ \\
\hline April - June 2010 & $\begin{array}{c}94.46 \\
(271.0)\end{array}$ & $\begin{array}{l}-14.64 \\
(320.6)\end{array}$ & $\begin{array}{c}220.9 \\
(352.7)\end{array}$ \\
\hline July - September 2011 & $\begin{array}{l}528.3^{* *} \\
(251.2)\end{array}$ & $\begin{array}{l}788.8^{* *} \\
(318.4)\end{array}$ & $\begin{array}{l}615.8^{*} \\
(360.6)\end{array}$ \\
\hline October - December 2011 & $\begin{array}{l}880.5^{* * *} \\
(278.7)\end{array}$ & $\begin{array}{l}881.8^{* *} \\
(354.4)\end{array}$ & $\begin{array}{l}1106.0^{* *} \\
(443.3)\end{array}$ \\
\hline January - March 2012 & $\begin{array}{l}562.9^{* *} \\
(261.8)\end{array}$ & $\begin{array}{l}733.1^{* *} \\
(339.8)\end{array}$ & $\begin{array}{l}733.7^{* *} \\
(342.0)\end{array}$ \\
\hline April - June 2012 & $\begin{array}{l}1000.9^{* *} \\
(391.3)\end{array}$ & $\begin{array}{l}793.9^{* *} \\
(385.5)\end{array}$ & $\begin{array}{l}2544.4^{* *} \\
(1203.6)\end{array}$ \\
\hline _cons & $\begin{array}{c}4543.1^{* * *} \\
(182.6) \\
\end{array}$ & $\begin{array}{c}4924.5^{* * *} \\
(232.0)\end{array}$ & $\begin{array}{c}4146.9^{* * *} \\
(244.7)\end{array}$ \\
\hline$N$ & 536 & 536 & 536 \\
\hline
\end{tabular}

Standard errors in parentheses

Source: author generated using NSS 66 and 68 data

${ }^{*} p<0.10,{ }^{* *} p<0.05,{ }^{* * *} p<0.01$

Table 7. Difference-in-Difference estimation using last and first quarter

\begin{tabular}{lccc}
\hline & All social groups & Hindus & SC_ST_Muslims \\
\hline diff-in-diff treatment effect & $-707.2^{*}$ & -741.7 & $-905.1^{*}$ \\
& $(411.8)$ & $(527.8)$ & $(517.4)$ \\
Treated districts=1;Zero otherwise & 90.45 & -80.82 & 67.37 \\
& $(307.5)$ & $(364.5)$ & $(323.8)$ \\
First quarter post-treatment(4-1) & $904.2^{* * *}$ & $1221.3^{* * *}$ & $797.5^{* *}$ \\
& $(286.0)$ & $(373.1)$ & $(337.2)$ \\
cons & & & $3908.0^{* * *}$ \\
& $4220.9^{* * *}$ & $4558.8^{* * *}$ & $(176.5)$ \\
\hline$N$
\end{tabular}

Standard errors in parentheses

Source: author generated using NSS 66 and 68 data

${ }^{*} p<0.10,{ }^{* *} p<0.05,{ }^{* * *} p<0.01$ 
Table 8. Difference-in-Difference estimation using last and second quarter

\begin{tabular}{lccc}
\hline & All social groups & Hindus & SC_ST_Muslims \\
\hline diff-in-diff treatment effect & -609.3 & -530.2 & -791.3 \\
& $(451.8)$ & $(566.2)$ & $(607.7)$ \\
Treated districts=1;Zero otherwise & & & 67.37 \\
& 90.45 & -80.82 & $(323.8)$ \\
Second quarter post-treatment(4-2) & $(307.5)$ & $(364.5)$ & $1252.0^{* *}$ \\
& $1225.7^{* * *}$ & $1248.0^{* * *}$ & $(480.6)$ \\
cons & $(326.5)$ & $(426.2)$ & $3908.0^{* * *}$ \\
& & & $(176.5)$ \\
\hline
\end{tabular}

Standard errors in parentheses

Source: author generated using NSS 66 and 68 data

${ }^{*} p<0.10,{ }^{* *} p<0.05,{ }^{* * *} p<0.01$

Table 9. Difference-in-Difference estimation using last and third quarter

\begin{tabular}{lccc}
\hline & All social groups & Hindus & SC_ST_Muslims \\
\hline diff-in-diff treatment effect & 184.2 & -137.8 & -75.74 \\
& $(439.8)$ & $(538.7)$ & $(512.6)$ \\
Treated districts=1;Zero otherwise & 90.45 & -80.82 & 67.37 \\
& $(307.5)$ & $(364.5)$ & $(323.8)$ \\
Third quarter post-treatment(4-3) & $659.4^{* *}$ & $976.3^{* *}$ & $655.5^{* *}$ \\
& $(296.3)$ & $(405.5)$ & $(291.0)$ \\
cons & & & $3908.0^{* * *}$ \\
& $4220.9^{* * *}$ & $4558.8^{* * *}$ & $(176.5)$ \\
\hline
\end{tabular}

Standard errors in parentheses

Source: author generated using NSS 66 and 68 data

${ }^{*} p<0.10,{ }^{* *} p<0.05,{ }^{* * *} p<0.01$

Table 10. Difference-in-Difference estimation using last and first quarter

\begin{tabular}{lccc}
\hline & All social groups & Hindus & SC_ST_Muslims \\
\hline diff-in-diff treatment effect & $-1011.0^{*}$ & -705.3 & -2578.1 \\
& $(572.3)$ & $(608.0)$ & $(1597.9)$ \\
Treated districts=1;Zero otherwise & 90.45 & -80.82 & 67.37 \\
& $(307.5)$ & $(364.5)$ & $(323.8)$ \\
Fourth quarter post-treatment(4-4) & & & $3250.5^{* *}$ \\
& $\left(472.0^{* * *}\right.$ & $1215.0^{* *}$ & $(1552.2)$ \\
cons & $(487.9)$ & $(470.1)$ & $3908.0^{* * *}$ \\
& & & $(176.5)$ \\
\hline
\end{tabular}

Standard errors in parentheses

Source: author generated using NSS 66 and 68 data

${ }^{*} p<0.10,{ }^{* *} p<0.05,{ }^{* * *} p<0.01$ 
Table 11. Results of Parallel Trend Assumption

\begin{tabular}{lccc}
\hline & All social groups & Hindus & SC_ST_Muslims \\
\hline Pre treatment quarter $2 \times$ treated districts & -532.5 & -749.3 & -195.8 \\
& $(513.2)$ & $(654.0)$ & $(571.5)$ \\
Pre treatment quarter 3 x treated districts & -309.2 & -488.8 & -34.01 \\
& $(473.4)$ & $(604.4)$ & $(517.8)$ \\
Pre treatment quarter 4 x treated districts & -636.6 & $-1229.0^{* *}$ & 283.7 \\
& $(564.5)$ & $(605.8)$ & $(796.8)$ \\
Post treatment quarter $1 \times$ treated districts & $-1016.3^{* *}$ & $-1230.5^{* *}$ & -939.1 \\
& $(452.4)$ & $(614.9)$ & $(571.0)$ \\
Post treatment quarter $2 \times$ treated districts & $-918.5^{*}$ & -1019.0 & -825.3 \\
& $(489.1)$ & $(648.1)$ & $(654.0)$ \\
Post treatment quarter $3 \times$ treated districts & -125.0 & -626.6 & -109.8 \\
& $(478.0)$ & $(624.2)$ & $(566.7)$ \\
Post treatment quarter $4 \times$ treated districts & $-1320.2^{* *}$ & $-1194.1^{*}$ & -2612.1 \\
\hline$N$ & $(602.2)$ & $(684.9)$ & $(1616.0)$ \\
\hline
\end{tabular}

Standard errors in parentheses

Source: author generated using NSS 66 and 68 data

${ }^{*} p<0.10,{ }^{* *} p<0.05,{ }^{* * *} p<0.01$ 